\title{
OPTIMALISASI PENGOLAHAN AIR LIMBAH INDUSTRI COLD STORAGESISTIM PLUG FLOW ACTIVATED SLUDGE
}

\section{OPTIMIZATION OF A WASTEWATER TREATMENT PLANT FROM COLD STORAGE INDUSTRY BY THE PLUG FLOW ACTIVATED SLUDGE SYSTEM}

\author{
Haspiadi \\ Balai Riset dan Standardisasi Industri Samarinda \\ Jl. Harmonika No. 3 Samarinda \\ e-mail : haspiadi_k@yahoo.com \\ Naskah diterima 26 September 2011, disetujui 19 Desember 2011
}

\begin{abstract}
ABSTRAK
Tujuan dari penelitian ini adalah untuk mengolah air limbah industri cold storage sistem plug flow activated sludge dalam skala laboratorium. Variasi proses yang digunakan adalah Waktu Tinggal Hidrolik (WTH) 0, 6, 12, 18 dan 30 jam serta jumlah biakan mikroba yang ditambahkan $0,5 \%, 1 \%, 1,5 \%$ dan $0 \%$ sebagai kontrol diambil dari parit sekitar industri cold storage. Hasil penelitian secara umum menunjukkan adanya penurunan kandungan polutan baik kontrol maupun dengan penambahan biakan mikroba. Effisiensi yang terbaik diperoleh untuk waktu tinggal hidrolik 30 jam tanpa penambahan biakan mikroba, dimana penurunan dicapai $75 \%$ TSS dan $87,76 \%$ COD. Sedangkan dengan penambahan biakan mikroba sebanyak $1 \%$ dicapai pada waktu 24 jam dengan penurunan TSS hingga $75,71 \%$ dan COD tercapai $83,33 \%$
\end{abstract}

Kata kunci : biakan mikroba, cold storage, COD, plug flow Activated sludge, TSS.

\begin{abstract}
ABSTRAC
The purpose of this research was to treat wastewater from cold storage industries using the plug flow activated sludge process at the laboratory scale. Various were that used in this research are 0 (control), 6, 12, 18 and 30 hours for Hidrolic Retention Time (HRT) and also numbers of seeding are 0,5\%, 1 $\%, 1,5 \%$, and $0 \%$ (control) taken from the ditches of cold storage industry. The research result indicated that generally, there was decrease of pollutant concentration in both control and treated samples by adding seeding. The best result in efficiency without adding seeding as a contorl were obtained in 30 hours, and were able to achieve a 75 percent Total Suspended Solid reduction and 87,76 percent removed COD. Whereas the best result in efficiency by adding seeding $1 \%$ was obtained in 24 hours, it was possible to acieve 75,71 percent Total Suspended Solid reduction and remove COD by 83,33 percent.
\end{abstract}

Keywords : cold storage, COD, plug flow activated sludge, seeding, TSS, 


\section{PENDAHULUAN}

eiring dengan berkembangan nya industri cold storage yang mengolah udang beku, tidak terlepas dari permasalahan lingkungan akibat limbah yang dihasilkan baik padat maupun cair. Dalam proses pengolahan udang untuk dibekukan banyak menggunakan air sebagai bahan pencuci. Dari proses pencucian ini akan terlarut atau terikut spesimen dari udang ke dalam air buangan yang banyak mengandung protein ataupun lemak daging. Akibatnya limbah cair yang dihasilkan dapat mengandung bahan organik yang tinggi.

Bahan organik dalam air limbah merupakan media yang baik untuk pertumbuhan bahan organik. Oleh karena itu, air limbah yang dihasilkan dari proses pada industri cold storage merupakan salah satu sumber pencemar. Air limbah yang dihasilkan selama proses pengolahan rata-rata 5 $\mathrm{m}^{3}$ setiap ton produk, dan bila tidak ditangani dengan baik sebelum dibuang ke badan penerima akan menimbulkan pencemaran lingkungan.

Karaktersitik air limbah dari proses pengolahan udang beku memiliki kandungan bahan organik baik terlarut maupun dalam bentuk tersuspensi yang bersifat muda terurai oleh mikroorganisma, sehingga memerlukan proses biologi. Data hasil uji dari beberapa industri cold storage di Kalimantan Timur menunjukkan masih adanya parameter uji melampaui baku mutu air limbah yang dipersyaratkan seperti TSS, BOD dan COD.

Masih tingginya beberapa parameter salah satunya dikarenakan oleh optimalisasi peroses yang dilakukan belum maksimal. Permasalahan yang dihadapi di lapangan adalah sistem atau teknologi yang digunakan dalam pengolahan air limbah masih sederhana berupa proses aerob saja, sehingga air limbah yang diolah belum memberikan hasil maksimal.
Oleh karena itu atas dasar sistem pengolahan air limbah yang ada di beberapa industri cold storage khususnya di Kalimantan Timur, serta kualitas air limbah hasil pengolahan yang belum sepenuhnya memenuhi baku mutu, maka dalam penelitian ini dilakukan optimalisasi pengolahan air limbah menggunakan sistem Lumpur aktif Plug-Flow Activated Sludge dengan berbagai kondisi waktu kontak dan persentase lumpur aktif. Diharapkan dengan sistem ini akan memperbesar kontak antara mikroorganisma dan bahan organik sehingga proses pengolahan akan lebih maksimal dan air limbah yang telah diolah dapat memenuhi baku mutu yang dipersyaratkan dan aman bagi lingkungan.

\section{BAHAN DAN METODA}

\section{Bahan dan Alat}

Bahan yang digunakan terdiri dari air limbah industri cold storage, kertas $\mathrm{pH}$, kertas saring whatman No. 42, aquadest, pupuk TSP, Urea dan pupuk NPK serta larutan gula. Peralatan terdiri dari satu unit pengolah limbah sistem plug flow activated sludge skala laboratorium dari bahan fiber dengan konfigurasi reaktor aerob sistem plug flow. Volume total 100 liter (volume efektif 75 L) dan bak penjernihan kapasitas $20 \mathrm{~L}$, pompa sirkulasi, aerator (sistem diffusi), timbang analitik, $\mathrm{pH}$ Meter, termometer, gelas ukur, erlenmeyer, labu ukur, sarung tangan, masker, termometer air raksa, , botol sampel, jerigen dan ember.

\section{Metode}

\section{Proses Pembibitan}

Lumpur selokan sekitar industri pengolahan udang diambil secara aseptik untuk proses seeding dan diberi media cair $(0,5 \%$ urea, $0,25 \% \mathrm{KCl}, 0,5 \%$ TSP dan $1 \%$ glukosa yang dilarutkan dengan $500 \mathrm{~mL}$ air (Sudaryati. at.al, 2009). Aktifitas mikroorganisma yang 
dihitung sebagai nilai Volatile Suspended Particulate.

\section{Proses Pengolahan}

Air limbah yang dihasilkan dari proses samping pengolahan udang terlebih dahulu dianalisa untuk mengetahui karakteristik kimia dan fisika, kemudian diumpankan ke dalam bak aerob. Bersamaan itu pula ditambahkan bahan lumpur yang telah diaktifkan (seeding), dilakukan pula dengan lumpur aktif tanpa penambahan sebagai kontrol. Pola distribusi aliran dari dasar ke permukaan (up flow), selanjutnya dialirkan ke dalam sistem plug flow paralel. Pada tahapan ini berlangsung proses biologis dengan biakan tersuspensi (suspended culture) dimana mikroorganisma akan menguraikan zat organik.

Selanjutnya biomassa yang banyak mengandung kultur biologi tersebut akan terendapkan dan diumpankan kembali dengan air limbah ke dalam bak aerob tersebut. Sistem aliran ini disebut juga lumpur aktif balik (Return Activated Sludge = RAS) yang akan membentuk lumpur campuran.

Dalam proses penguraian ditetapkan waktu kontak dengan sistem hidrolik selama $6,12,18,24,30$ jam serta 0 jam sebagai kontrol serta prosentase penggunaan lumpur aktif 0 $\%, 0,5 \%, 1 \%$ dan $1,5 \%$ dari volume efektif limbah yang akan diolah (\% berat/ volume).

Adapun laju sirkulasi air limbah yang masuk ke dalam reaktor aerob dihitung berdasarkan Food to Microorganism Ratio (F/M). Ditetapkan F/M rasio dalam proses ini sebesar 0,2 $\mathrm{mg} / \mathrm{L}$ (proses konvensional 0,2 - 0,5 $\mathrm{mg} / \mathrm{L} \mathrm{BOD/hari/mg/L} \mathrm{MLSS).} \mathrm{Penetapan}$ laju sirkulasi air limbah ( $F / M)$ menggunakan rumus sebagai berikut :

$$
\frac{F}{M}=\frac{Q \times B O D 5}{M L S S \times V}
$$

Dimana :

$\mathrm{Q}=$ Laju alir air limbah ( L/menit)

$\mathrm{BOD}=\mathrm{BOD}_{5}$ rata-rata sampel yang akan diolah (mg/L)

MLSS $=$ adalah Mixed Liquor

Suspended Solid (mg/L)

dihitung dengan mengukur

jumlah suspended dalam air

limbah yang disaring dan $105^{\circ} \mathrm{C}$ dikeringkan pada suhu

$\mathrm{V}=$ Volume tangki aerasi (L).

\section{Analisa Data}

Pengujian sampel dilakukan terhadap sampel sebelum diolah sebagai kontrol dan sesudah diolah dengan parameter $\mathrm{pH}$ sesuai $\mathrm{SNI} 06$ 6989.11-2004, TSS sesuai SNI 066989.3-2004, COD sesuai SNI 066989.15-2004.

Selain itu dihitung pula laju endapan sedimen sesuai Standard Methode, edisi ke-20 $0^{\text {th }}$ (2540-E) dengan cara menghitung Sludge Volume Indeks (SVI) dengan cara lumpur campuran dimasukkan dalam labu ukur 1 liter dan biarkan selama 30 menit kemudian dicatat volume sludge (SV). Perhitungan dengan persamaan berikut

Jadi : $\quad$ SVI $=\frac{\text { SV } \times 1000}{\text { MLSS }}$

Dimana :

Hitung pula TSS (MLSS)

$\mathrm{SVI}=$ sludge volume indeks

$\mathrm{SV}=$ volume sludge yang terbentuk dalam labu ukur $(\mathrm{mL})$

MLSS (Mixer Liquid Suspended Solid $)=$ dihitung sebagai nilai VSS (mg/L).

\section{HASIL DAN PEMBAHASAN}

\section{Penetapan Laju Alir Air Limbah}

Hasil perhitungan laju alir air limbah berdasarkan kisaran nilai BOD sebesar $153,5 \mathrm{mg} / \mathrm{L}$ dan nilai Mixed Liquer Suspended Solid sebesar 76,8 $\mathrm{mg} / \mathrm{L}$ serta volume evektif bak sebesar $72 \mathrm{~L}$ diperoleh $\mathrm{Q}$ (L/menit) sebesar 7,5 L/menit. Nilai ini kemudian ditetapkan sebagai nilai laju alir air limbah yang 
masuk ke dalam bak aerob secara kontinyu.

\section{Biakan Mikroba.}

Biakan mikroba yang diberi nutrien urea $0,5 \%, \mathrm{KCl} 0,25 \%$, TSP $0,25 \%$ dan glukosa $1 \%$ dan diaerasi selama 5 hari. Pemberian nutrien seperti nitrogen dan phosfor diperlukan untuk pertumbuhan mikroorganisma (Anonim, 2009) Hasil uji dari Volatile Suspended Partikel (VSP) sebagai indikator aktifitas mikroorganisma dalam biakan mikroba rata-rata sebesar $23348 \mathrm{mg}$ volatile solid /L.

Pengaruh Waktu Tinggal dan Jumlah Biakan Mikroba Terhadap Efektifitas Pengolahan Sistem Plug Flow Activated Sludge.

Adapun hasil pengolahan air limbah menggunakan lumpur aktif dengan sistem Plug Flow Activated Sludge, ditunjukkan adanya penurunan parameter TSS dan COD serta perubahan nilai $\mathrm{pH}$ air limbah sebagaimana uraian di bawah ini.

\section{Nilai pH Sampel Uji Air Limbah Sebelum dan Sesudah Pengolahan}

Parameter $\mathrm{pH}$ yang didefenisikan sebagai konsentrasi ion hidrogen bervariasi dalam setiap jenis air limbah. Pada tahap awal pengolahan air limbah industri cold storage sistem plug flow activated sludge pengaturan $\mathrm{pH}$ tidak dilakukan karena hasil uji untuk air limbah awal yang diolah masih berada pada kisaran $\mathrm{pH}$ optimum bagi pertumbuhan mikroorganisma pengurai yaitu 6,5 sampai dengan 7,5.

Nilai $\mathrm{pH}$ air limbah industri cold storage setelah diolah menunjukkan perbedaan yang tidak terlalu besar antara kombinasi perlakuan jumlah lumpur aktif (biakan mikroba) dengan Waktu Tinggal Hidrolik (WTH). Walaupun nilai $\mathrm{pH}$ meningkat namun masih dalam kisaran nilai $\mathrm{pH}$ yang optimum untuk suatu proses biologi (aerob). Menurut Said, N.D, 2002 nilai $\mathrm{pH}$ yang optimum untuk suatu proses aerob berkisar antara 6,5 sampai dengan 8,5.

Kenaikan $\mathrm{pH}$ air limbah setelah diolah dengan Waktu Tinggak Hidrolik (WTH) berturut-turut 6, 12, 18, 24 dan 30 jam sebagaimana ditunjukkan pada Gambar 2.

Kenaikan nilai $\mathrm{pH}$ air limbah seteleh diolah dengan waktu tinggal hidrolik yang bervariasi dapat disebabkan karena air limbah selama proses mengalami proses oksidasi, selanjutnya dengan proses respirasi mikroorganisma menghasilkan $\mathrm{CO}_{2}$. Nilai $\mathrm{pH}$ air limbah pada kondisi tersebut basa (alkali) dan menghasilkan senyawa bikarbonat $\left(\mathrm{HCO}^{-}\right)$dan secara alami mengalami kenaikan $\mathrm{pH}$, sebagaimana ditunjukkan reaksi berikut :

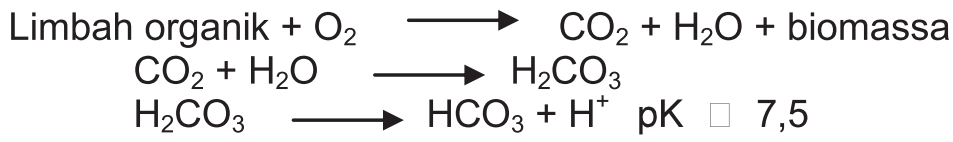




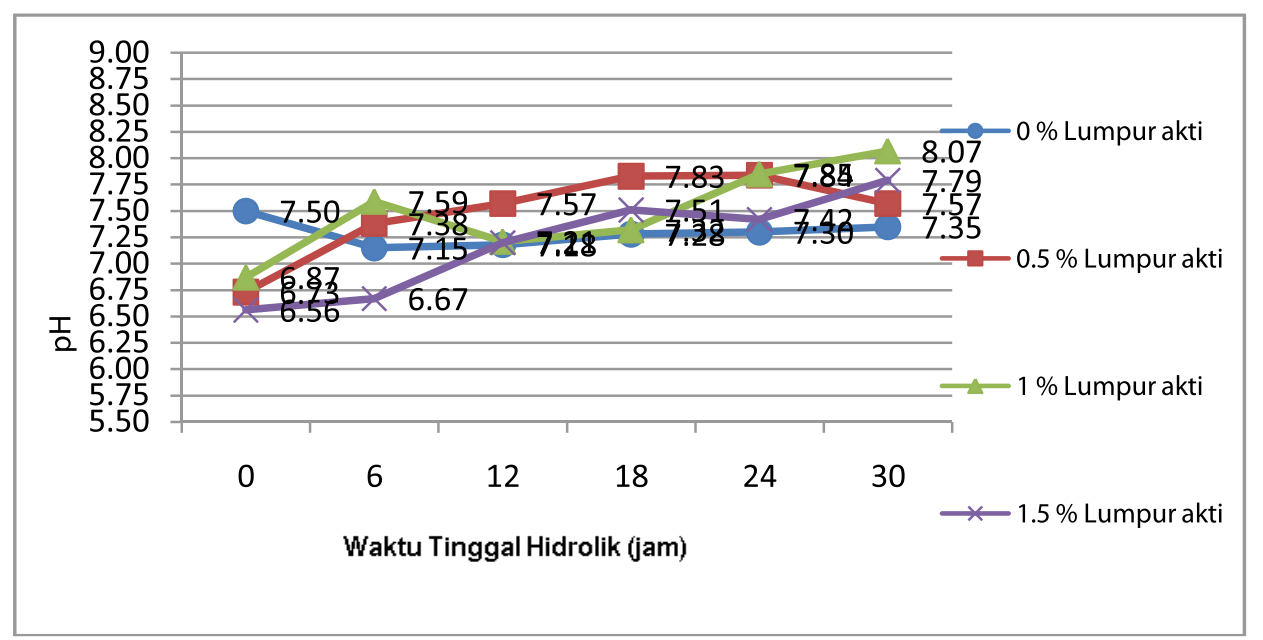

Gambar 2. Nilai pH limbah cair sebelum dan sesudah pengolahan

Berdasarkan hasil analisa statistik pengukuran nilai $\mathrm{pH}$ terlihat pada perlakuan dengan keempat persentase lumpur aktif yang digunakan yaitu $0,5 \%$, $1 \%$ dan $1,5 \%$ serta $0 \%$ sebagai kontrol menunjukkan pengaruh nyata terhadap nilai $\mathrm{pH}$, demikian pula dengan faktor Waktu Tinggal Hidrolik (WTH) 0 jam sebagai kontrol, 6, 12, 18, 24 dan 30 jam. Berbeda dengan interaksi antara jumlah lumpur dan Waktu Tinggal Hidrolik tidak menunjukkan perbedaan yang nyata.

Bila dibandingkan dengan baku mutu air limbah kegiatan industri cold storage sesuai dengan Keputusan Gubernur Kalimantan Timur No. 26 tahun 2002 tentang Baku Mutu Limbah Cair Bagi Kegiatan Industri dan Usaha lainnya dalam Propinsi Kalimantan Timur dari semua perlakuan masih dalam kisaran nilai yang diperbolehkan untuk dibuang ke lingkungan yaitu $\mathrm{pH}$ antara 6 sampai dengan 9 .

\section{Nilai Total Suspended Solid (TSS) Air Limbah Sebelum dan Sesudah Pengolahan.}

Total Padatan Tersuspensi (TSS) yang diartikan sebagai suspensi tertahan pada kertas saring whatman berpori $0,45 \mu \mathrm{m}$ yang kemudian dikeringkan hingga berat konstan pada suhu $103^{\circ} \mathrm{C}-105^{\circ} \mathrm{C}$, merupakan salah satu indikator kandungan polutan dalam air limbah. Partikel tersuspensi yang terkandung dalam air limbah industri cold storage berasal dari sisa proses produksi baik yang bersifat terlarut maupun tidak larut.

Efektifatas pengolahan air limbah dengan kandungan suspensi tinggi dapat dilakukan salah satunya dengan proses lumpur aktif. Proses ini merupakan aktivitas mikroorganisma untuk merombak bahan organik baik terlarut maupun tidak terlarut yang kemudian dikonversi menjadi flok-flok halus yang disebut dengan suspension microbio yang mudah terendapkan.

Hasil pengujian Total Suspended Solid (TSS) air limbah dari kombinasi perlakuan menggunakan lumpur aktif $0 \%$ sebagai kontrol, $0,5 \%, 1 \%$ dan $1,5 \%$ serta Waktu Tinggal Hidrolik (WTH) 0 jam, 6 jam, 12 jam, 18 jam, 24 jam dan 30 jam menunjukkan penurunan yang cukup besar sebagaimana pada Gambar 3 


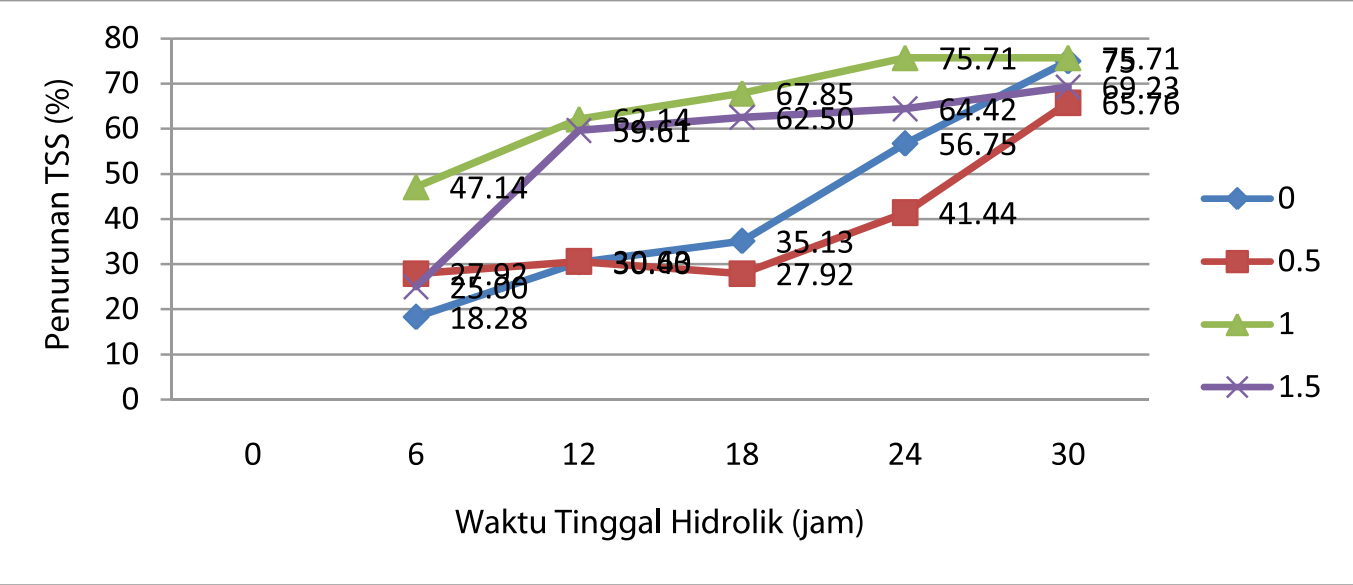

Gambar 3. Nilai TSS air limbah sebelum dan sesudah pengolahan

Penurunan Total Suspended Solid (TSS) terjadi karena perombakan bahan organik terlarut dan tidak larut dalam bentuk suspensi oleh mikroorganisma pada kondisi aerob dengan Waktu
Tinggal Hidrolik yang cukup, sebagaimana dijelaskan oleh Eckenfelder W.W, 1989 dengan persamaan berikut :

Organik $+\mathrm{a}^{\prime} \mathrm{O}_{2}+\mathrm{N}+\mathrm{P} \quad \underset{\mathrm{k}}{\stackrel{\mathrm{sel}}{\longrightarrow}}$ sel-sel baru+ $\mathrm{CO} 2+\mathrm{H} 2 \mathrm{O}+\begin{aligned} & \text { residu terlarut yang } \\ & \text { tidak terurai }\end{aligned}$

Sel-sel $+b^{\prime} \mathrm{O}_{2}$

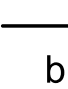

$\mathrm{CO} 2+\mathrm{H} 2 \mathrm{O}+\mathrm{N}+\mathrm{P}+$ sel-sel residu yang

tidakterurai

Penurunan TSS dengan penggunaan lumpur aktif $0,5 \%$ dan WTH 6 jam nilai TSS semula $111 \mathrm{mg} / \mathrm{L}$, mengalami penurunan sebesar $27,92 \%$ dan untuk WTH 12 jam penurunan sebesar 30,63 \%, kemudian WTH 18 jam penurunannya sebesar $27,92 \%$, WTH 24 jam penurunan sebesar 41,44 $\%$ dan terakhir WTH 30 jam penurunan sebesar $65,96 \%$. Demikian pula dengan penggunaan lumpur aktif $1 \%$ dengan WTH 6 jam nilai TSS semula $140 \mathrm{mg} / \mathrm{L}$, mengalami penurunan sebesar $47,14 \%$ dan untuk WTH 12 jam penurunan sebesar 62,14 \%, kemudian WTH 18 jam penurunan sebesar $67,85 \%$, WTH 24 jam penurunan sebesar $75,71 \%$ dan terakhir WTH 30 jam penurunan sebesar $75,71 \%$.

Selanjutnya untuk pengguna an lumpur biakan mikroba $1,5 \%$ penurunan
TSS dengan Waktu Tinggal Hidrolik 6 jam sebesar 25,08 \%, untuk WTH 12 jam penuruanan sebesar $59,61 \%$, dan untuk WTH 18 jam penurunan sebesar $62,50 \%$, untuk WTH 24 jam penurunan sebesar $64,42 \%$ dan WTH 30 jam penurunan tetap $64,23 \%$. Hal yang sama untuk pengolahan air limbah tanpa penggunaan lumpur biakan mikroba, persentase penurunan TSS hampir sama dengan pengolahan air limbah menggunakan biakan mikroba yaitu Waktu Tinggal Hidrolik 6 jam sebesar 18,24 \%, untuk WTH 12 jam penuruanan sebesar 30,40 \%, dan untuk WTH 18 jam penurunan sebesar $35,13 \%$, untuk WTH 24 jam penurunan sebesar $56,75 \%$ dan WTH 30 jam penurunan $75,00 \%$. 
Tabel 1. Nilai Sludge Volume Indeks (SVI) Terhadap Penurunan Nilai TSS

\begin{tabular}{|c|c|c|c|c|c|c|c|c|}
\hline \multirow{2}{*}{$\begin{array}{c}\text { Waktu } \\
\text { Tinggal } \\
\text { (jam) }\end{array}$} & \multicolumn{2}{|c|}{$\begin{array}{c}\text { Tanpa } \\
\text { Lumpur Aktif }\end{array}$} & \multicolumn{2}{|c|}{$\begin{array}{c}0.5 \% \\
\text { Lumpur Aktif }\end{array}$} & \multicolumn{2}{|c|}{$\begin{array}{c}1 \% \\
\text { Lumpur Aktif }\end{array}$} & \multicolumn{2}{|c|}{$\begin{array}{c}1,5 \% \\
\text { Lumpur Aktif }\end{array}$} \\
\hline & ng/L) & SVI & $\begin{array}{l}\text { TSS } \\
\text { (mg/L) }\end{array}$ & SVI & $\begin{array}{c}\text { TSS } \\
\text { (mg/L) }\end{array}$ & SVI & $\begin{array}{c}\text { TSS } \\
\text { (mg/L) }\end{array}$ & SVI \\
\hline 6 & 121 & 2702 & 80 & 3947 & 74 & 2857 & 78 & 3125 \\
\hline 12 & 103 & 1562 & 77 & 1538 & 53 & 2857 & 42 & 2702 \\
\hline 18 & 96 & 1041 & 80 & 1250 & 45 & 1111 & 39 & 1282 \\
\hline 24 & 64 & 970 & 65 & 643 & 35 & 934 & 37 & 1190 \\
\hline 30 & 37 & 826 & 38 & 625 & 35 & 676 & 32 & 641 \\
\hline
\end{tabular}

Data pada Tabel 2 diatas menunjukkan bahwa penurunan Total Suspended Solid (TSS) berkorelasi dengan besarnya kenaikan laju endapan padatan yang dihitung sebagai Sludge Volume Indeks (SVI). Hubungan antara TSS dan laju endapan padatan dihitung sebagai SVI untuk pengolahan menggunakan lumpur aktif $0,5 \%$ menunjukkan hubungan linear dengan korelasi negatif sebagaimana persamaan adalah $\mathrm{y}=43,44 \mathrm{x}-1353$ dan nilai korelasi $(r)=0,321$, dimana $y$ adalah Laju Endapan (SVI) dan $\mathrm{x}$ adalah nilai TSS.

Selanjutnya untuk perlakuan $1 \%$ lumpur aktif dan Waktu Tinggal Hidrolik $6,12,18,24$ dan 30 jam, juga menunjukkan korelasi negatif yang sama dengan $0,5 \%$ dimana persamaannya adalah $y=58,15 x-1129$ dan nilai korelasi $(r)=0,761$, dimana y adalah Laju Endapan (SVI) dan x adalah nilai TSS. Demikian pula dengan pengolahan menggunakan lumpur aktif 1,5\% dengan Waktu Tinggal Hidrolik 6, $12,18,24$ dan 30 jam dan proses plug flow activated sludge juga menunjukkan korelasi negati dengan persamaan $\mathrm{y}=$ $46,96 x+353,3$ dan nilai korelasi $(r)=$ 0,661 dimana y adalah Laju Endapan (SVI) dan $x$ adalah nilai TSS.

Untuk pengolahan air limbah tanpa penambahan lumpur yang mengandung biakan mikroba, yang hanya menggunakan lumpur hasil proses berupa sel-sel yang disirkulasi. Penurunan nilai TSS cukup besar untuk setiap retensi waktu yang berbeda. Besarnya penurunan sejalan dengan kenaikan waktu tinggal hidrolik. Hal ini pula dapat dilihat dari besarnya laju endapan padatan yang terjadi (Sludge
Volume Indeks) yang ditunjukkan dengan hubungan linera dengan korelasi negatif sebagaimana persamaan $y=18,40 x+129,4$ dan nilai korelasi $(r)=0,642$, dimana y adalah Laju Endapan (SVI) dan $x$ adalah nilai TSS serta.

Bila dilihat penurunan TSS pada gambar 3, penurunan cukup besar untuk setiap WTH dengan masing-masing penggunaan lumpur aktif berbeda, Menurunnya TSS ini karena flok-flok (lapisan tipis) yang terbetuk kemudian mengalami sedimentasi. Proses sedimentasi ini disebut dengan sistem flocculant yaitu terjadinya sel-sel aglomerat selama proses pengendapan dan mengalami perubahan ukuran menjadi biomassa (Anonim, 2008)

Berdasarkan analisa statistik hasil uji TSS terlihat pada perlakuan tiga jenis volume lumpur yang berbeda yaitu $0,5 \%, 1 \%$ dan $1,5 \%$ serta $0 \%$ sebagai kontrol menunjukkan pengaruh yang berbeda nyata terhadap penurunan TSS, demikian pula dengan faktor Waktu Tinggal Hidrolik (WTH) 0 jam sebagai kontrol, 6, 12, 18, 24 dan 30 jam. Namun untuk interaksi antara jumlah lumpur dan Waktu Tinggal Hidrolik tidak berbeda nyata.

Hasil uji TSS bila dibandingkan dengan baku mutu limbah cair kegiatan industri cold storage sesuai dengan Keputusan Gubernur Kalimantan Timur No. 26 tahun 2002 tentang Baku Mutu Limbah Cair Bagi Kegiatan Industri dan Usaha lainnya dalam Propinsi Kalimantan Timur dari semua perlakuan baik dengan menggunakan lumpur aktif $0,5 \%, 1 \%$ dan $1,5 \%$ maupun tanpa lumpur aktif diolah dengan sistem plug flow activated sludge secara umum 
setelah pengolahan dengan Waktu Tinggal Hidrolik (WTH) 6 jam saja telah memenuhi baku mutu yang dipersyaratkan untuk dibuang ke lingkungan yaitu kurang dari 100 mg/L.

\section{Nilai COD Sampel Uji Air Limbah Sebelum dan Sesudah Pengolahan}

COD (Chemical Oxigen Demand) diartikan sebagai jumlah (mg) oksigen yang dibutuhkan untuk mengoksidasi bahan organik dalam satu liter air dengan menggunakan oksidator kimia. COD merupakan salah satu indikator pencemaran yang disebabkan oleh bahan organik. Dari nilai COD air limbah industri cold storage sebelum diolah antara $250 \mathrm{mg} / \mathrm{L}$ sampai dengan 640 $\mathrm{mg} / \mathrm{L}$ sangat cocok diolah dengan proses lumpur aktif sebagaimana dijelaskan oleh Grady dan Lim 1980, bahwa jika konsentrasi organik yang diukur sebagai nilai COD lebih besar dari $50 \mathrm{mg} / \mathrm{L}$ sangat efektif menggunakan pengolahan secara lumpur aktif .

Hasil uji dari pengolahan air limbah dengan sistem plug flow activated sludge menggunakan biakan mikroba (lumpur yang telah diaktifkan) $0 \%$ (sebagai kontrol), $0,5 \%, 1 \%$ dan $1,5 \%$ dengan waktu tinggal hidrolik ditetapkan $6,12,18,24,30$ dan 0 jam sebagai kontrol mengalami penurunan.

Penggunaan lumpur $0,5 \%$ untuk WTH 6 jam dari kandungan COD awal sebesar 506,75 mg/L turun sebesar $20,35 \%$, untuk WTH 12 jam penurunan sebesar $32,80 \%$, untuk WTH 18 jam penurunan sebesar $32,87 \%$, dengan WTH 24 jam sebesar 47,97 \%, dan WTH 30 jam sebesar $61,76 \%$. Selanjutnya penggunaan $1 \%$ lumpur aktif dengan WTH 6 jam penurunan sebesar 52,70 \%, dengan WTH 12 jam penurunan sebesar $63,68 \%$, untuk WTH 18 jam penurunan sebesar 71,42 $\%$, untuk WTH 24 jam penurunan sebesar $83,33 \%$ dan untuk WTH 30 jam penurunan sebesar $85,34 \%$.

$$
\text { Demikian pula dengan }
$$

penggunaan lumpur $1,5 \%$, COD awal sebelum diolah sebesar $425,50 \mathrm{mg} / \mathrm{L}$ dan setelah diolah dengan WTH 6 jam terjadi penurunan COD sebesar 33,63 $\%$, kemudian pengolahan dengan $\mathrm{WTH}$ 12 jam penurunan sebesar 47,65 \%, untuk WTH 18 jam penurunan sebesar $77,09 \%$, untuk WTH 24 jam penurunan sebesar 85,93 \% dan terakhir dengan WTH 30 jam penurunan COD sebesar $92,84 \%$.

Selain pengolahan air limbah dengan penambahan biakan mikroba yang dibuat, juga dilakukan pengolahan tanpa penambahan biakan mikroba untuk mengetahui efektifitas proses plug flow. Lumpur yang digunakan hanya menggunakan lumpur dari hasil samping proses aerob yang cukup besar sebagaimana data perhitungan SVI pada Tabel 2. Dalam proses ini lumpur yang terbentuk terjadi dari proses secara langsung hasil perombakan bahan organik oleh mikroba membentuk flok-flok yang kemudian terendapkan membentuk lumpur (sludge) dengan kandungan mikroorganisma yang cukup tinggi. Selanjutnya lumpur yang terbentuk dialirkan kembali atau return activated sludge (RAS) ke dalam bak aerob.

Hasil uji tanpa penambahan biakan mikroba yang dibuat juga mengalami penurunan kandungan bahan organik yang diukur sebagai nilai COD. Pada tahap ini nilai COD awal sebesar 254,60 mg/L, dengan pengolahan selama WTH 6 jam nilai COD menurun sebesar 22,20 \%, dengan WTH 12 jam penurunan sebesar 42,20\%, untuk WTH 18 jam penurunan sebesar $64,43 \%$ dan untuk WTH 24 jam penurunan sebesar 71,00 $\%$, sedangkan untuk WTH 30 jam penurunan sebesar $87,76 \%$.

Penurunan nilai COD ini menunjukkan efektifitas mikro organisma untuk merombak bahan organik terlarut maupun tidak terlarut dalam kondisi aerob yang baik. Pola penurunan nilai COD seperti ditunjukkan Gambar 4. 


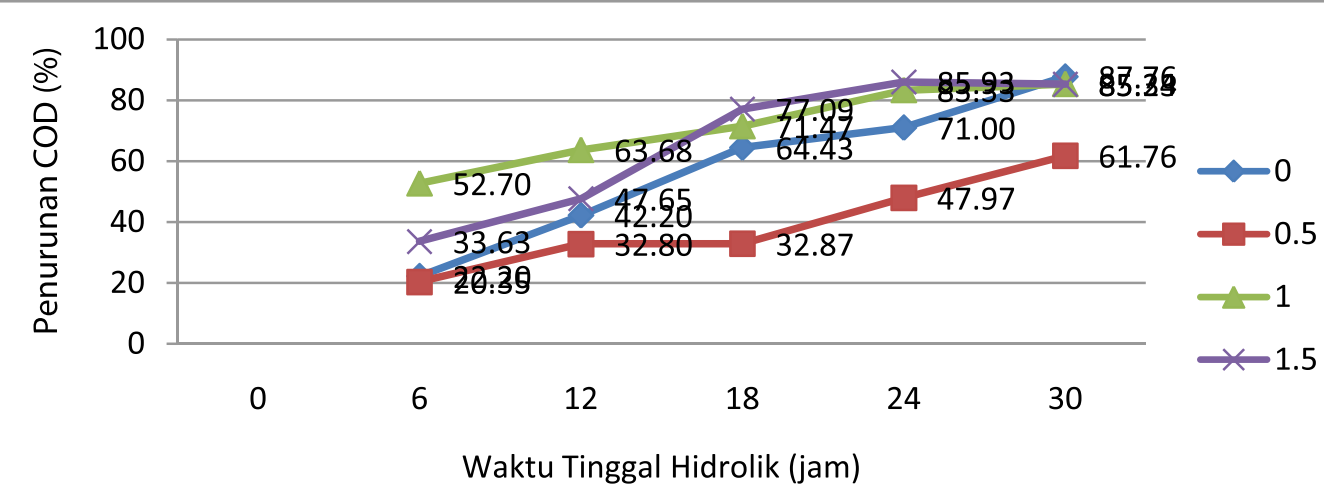

Gambar 4. Nilai COD air limbah sebelum dan sesudah pengolahan

Berdasarkan analisa statistik pengaruh pengolahan air limbah industri cold storage sistem plug flow activated sludge bahwa perlakuan keempat komposisi lumpur berpengaruh sangat nyata terhadap penurunan nilai COD, demikian pula dengan perbedaan Waktu Tinggal Hidrolik (WTH) 6,12,18,24 dan 30 serta 0 jam sebagai kontrol menunjukkan pengaruh sangat nyata. Hal yang sama juga untuk interaksi antara faktor lumpur aktif dan WTH menunjukkan adanya pengaruh yang nyata.

Hasil uji bila dibandingkan dengan baku mutu limbah cair kegiatan industri cold storage sesuai dengan Keputusan Gubernur Kalimantan Timur No. 26 tahun 2002 tentang Baku Mutu Limbah Cair Bagi Kegiatan Industri dan Usaha lainnya dalam Propinsi Kalimantan Timur untuk perlakuan tanpa penambahan biakan mikroba dengan WTH 6 jam telah memenuhi yaitu kurang dari $200 \mathrm{mg} / \mathrm{L}$, sedangkan untuk penggunaan lumpur biakan mikroba $1 \%$ dan $1,5 \%$ masing-masing dengan WTH 18 jam. Namun karena pola penurunan sangat dipengaruhi oleh nilai COD awal, sehingga penurunan yang paling optimal bila dilihat dari besarnya persentase adalah WTH 30 jam dengan penggunaan lumpur aktif $1,5 \%$ sebesar $93 \%$.

\section{KESIMPULAN DAN SARAN}

Dari proses pengolahan yang dilakukan baik tanpa penambahan lumpur aktif (biakan mikroba) maupun dengan penambahan lumpur aktif (biakan mikroba), keduanya efektif menurunkan nilai TSS dan COD memenuhi baku mutu limbah cair yang dipersyaratkan untuk industri cold storage. Waktu Tinggal Hidrolik (WTH) yang optimal untuk pengolahan air limbah tanpa penggunaan lumpur aktif (lumpur aktif yang digunakan terbentuk dari proses aerob) adalah WTH sebesar 30 jam dan dengan penggunaan lumpur aktif (biakan yang dibuat) waktu yang optimal adalah Waktu Tinggal Hidrolik (WTH) selama 24 jam dengan jumlah lumpur $1 \%$. Dalam proses pengolahan air limbah sistem lumpur aktif melewati aliran plug flow, agar bahan toksit yang terkandung dalam air limbah dapat dieleminir terlebih dahulu sebelum diumpankan ke dalam bak aerob karena dapat mempengaruhi kerja mikroorganisma merombak bakan organik.

\section{DAFTAR PUSTAKA}

Anonim 2002. Keputusan Gubernur Kalimantan Timur No. 26 tahun 2002 tentang Baku Mutu Limbah Cair bagi Kegiatan Industri dan Usaha lainnya dalam Propinsi Kalimantan Timur.

Anonim, 2008. Microorganisms and Their Role in the Activated-Sludge Process, http://www.college.ucla.edu/webpr oject/micro7/studetsprojects $7 /$ rude 
rlasludge2.htm. Diakses pada tanggal 13/01/2010.

Anonim, 2009. Discription of Commonly Considered Water Quality Constituents.

http://www.gaepd.org/Filer

.PDF/techniquide/wpd/devwtrplanb.pdf. Diakses pada tanggal 23/11/2010

BSN, 2004. Standard Nasional Indonesia (SNI) 06-6989.3-2004, Air dan Air LImbah-Bagian 3: Cara Uji Padatan Tersuspensi Total secara Gravimetri. BSN Jakarta

BSN, 2004. Standard Nasional Indonesia (SNI) 06-6989.11-2004, Air dan Air Limbah Bagian 11: Cara Uji Derajat Keasaman dengan Menggunakan $\mathrm{pH}$ Meter, BSN Jakarta

BSN, 2004. Standard Nasional Indonesia (SNI) 06-6989.15-2004 Air dan Air Limbah Bagian 15: Cara Uji Kebutuhan Oksigen Kimiawi Refluks Terbuka secara Titrimetri, BSN Jakarta.

Eckenfelder W. 1989. Industrial Water Pollution Control., Secon edition de Nevers N. Air Pollution Control Engineering. Mc Graw Hill series in Water Resources and
Environmental Engineering. Edisi International 1995.

Grady. C.P Lesli dan Lim Henry C, 1980, Biological Wastewater Treatment. Teory and applications

Said Nusa I, Widaya W, Herlambang A Machdar E.C. 2002. Aplikasi teknologi Biofilter untuk Pengolahan Air Limbah Industri Kecil Tekstil.

Standard Methode, Standard Methode for the Examination of Water and Wastewater, $20^{\text {th }} \quad$ edition. American Public Health Assiciation American Water Works Association. Water Environmental Federation, 2540-E

Sudaryati, N.L.G, Kassa, I.W, Suyasa, I.W.B. Pemanfaatan Sedimen Perairan Tercemar Sebagai Bahan Lumpur Aktif dalam Pengolahan Limbah Cair Industri Tahu. Jurnal ISSN: 1907-5626

Yanuar Noor Akbar, 2008. Desain Pengolahan Air Limbah Kawasan Pengolahan Ikan (industri Makanan dengan Bahan Baku Udang) UniversitasDiponegoro Semarang. 